\title{
Editorial
}

\section{Ainda sobre publicações: cientificas ou ficcionais}

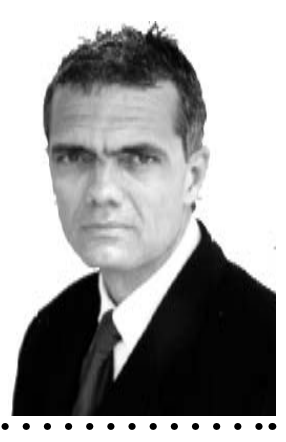

Marco Antonio Guimarães da Silva

No editorial passado, focalizei o espaço literário dos escritores de ficção e dos escritores de artigos científicos. Pretendo agora, en passant, observar as dificuldades que esses autores encontram para publicar seus livros de ficção ou seus artigos científicos.

No que diz respeito à publicação de um artigo cientifico, o pesquisador submete o que produziu e escreveu ao comitê editorial de uma revista cientifica ou de um periódico. Esse comitê é constituído em sua grande maioria por doutores, com experiência em pesquisa e, excepcionalmente, por um pequeno percentual de mestres ou de profissionais clínicos de comprovada experiência. Essas revistas científicas são normalmente avaliadas, aqui no Brasil, pelo fator de impacto que possuem e pela classificação Qualis da CAPES. Ter um artigo aceito e publicado por um periódico que tenha um fator de impacto muito alto, ou com uma pontuação Qualis A internacional, pode levar até dois anos. A demora se justifica, na maioria das vezes, porque é grande o número de artigos enviados a essas revistas ou porque o artigo caiu em exigência e o autor deverá proceder às correçóes exigidas pelo parecerista. Pelo que sei, não há privilégios para fulano ou cicrano: os artigos bons são sempre bem vindos e publicados, seja o autor um eminente cientista sênior ou um neófito na pesquisa. Como o objetivo desses periódicos científicos é o de ser o canal entre a produção científica do pesquisador e o público formado também por pesquisadores ou profissionais afins, descaracteriza-se, nesse caso, o aspecto meramente comercial da veiculação do produto (o artigo científico publicado).

Mas e os autores de ficção? Teriam eles oportunidade de publicar as suas produçóes literárias, que, em alguns casos, consumiram-lhes anos e anos de dedicação? Bem, aqui a história é outra. Parece ser o mercado que regula as coisas. Seja a obra boa ou não.
Para começo de conversa, sugere-se que o escritor tenha um bom agente literário, mas é praticamente impossível ter um, se você é um novato. Se considerarmos que um agente literário ganha um pequeno percentual sobre o que o autor ganha (normalmente 10\% sobre o preço de capa), ele só conseguirá ter algum lucro compensador, se o autor vender muito. Entende-se, portanto, porque os autores ainda desconhecidos do grande público são, em sua grande maioria, rejeitados por esses agentes.

Há centenas e centenas de novos escritores que tentam o mercado editorial; alguns medíocres, outros bons e outros muito bons, à altura de autores já consagrados pela crítica e pelo público. Alguns desses autores, não tendo encontrado um agente que os representasse, enviam os seus manuscritos diretamente para as editoras. Mais uma vez, indo em direção oposta ao que ocorre no mercado editorial cientifico, o autor iniciante que tem o seu livro aceito comprou o bilhete premiado da Mega-sena, cujas chances de ganhar são de um para cinquenta milhóes. As editoras não querem correr riscos. É bem possível que os novos escritores, que já tiveram a decepção da rejeição, tenham se perguntado: se os agentes literários e as editoras só aceitam os autores conhecidos, como e quando poderemos nos tornar conhecidos? Suponho que resposta seria algo parecido com: reconhecemos que a pergunta procede, mas é assim que o mercado funciona. Só lhes resta rezar para tirar a "sorte grande na loteria".

$\mathrm{O}$ destino tem sido muito generoso com as escolhas que faço e gostaria aqui de celebrar, com os que me tem me acompanhado até hoje, o fato de ter firmado contrato com a Editora paulista Octavo (http://www.octavo.com.br), para a edição, ainda este ano, do meu segundo romance, sem a necessidade de intermediação de um agente literário. 